\title{
NOTES
}

\section{THE EXPANDING DEFINITION OF "SECURITY": SALE-LEASEBACKS AND OTHER COMMERCIAL LEASING ARRANGEMENTS}

The scope of the term "security" under the federal securities acts" has in recent years received considerable attention from commentators. Articles have dealt with the subject in general, ${ }^{2}$ as well as with such specific arrangements as real estate offerings and condominiums, ${ }^{3}$ founder/member contracts, ${ }^{4}$ and franchises. ${ }^{5}$ However, to

1. The term "security" is defined in five federal acts: Securities Act of $1933, \S 2(1), 15$ U.S.C. $\S 77 \mathrm{~b}(1)$ (1970); Securities Exchange Act of 1934, $\S 3(\mathrm{a})(10), 15$ U.S.C. $\S 78 \mathrm{c}(\mathrm{a})(10)$ (1970); Public Utility Holding Company Act of 1935, § 2(a)(16), 15 U.S.C. $\S 79 b(a)(16)$ (1970); Investment Company Act of 1940, § 2(a)(35), 15 U.S.C. $\S 80 \mathrm{a}-2(\mathrm{a})(36)(1970)$; Investment Advisers Act of 1940, $\S 202(a)(17), 15$ U.S.C. $\S 80 \mathrm{~b}-2(a)(18)(1970)$.

These definitions are virtually identical and any effect of such differences as there are has been largely eliminated by judicial interpretation. See Tcherepnin v. Knight, 389 U.S. 332, 344 (1967) (omission of "evidence of indebtedness" in 1934 Act of no" "controlling significance"); Sanders v. John Nuveen \& Co., 463 F.2d 1075 (7th Cir.), cert. denied, 41 U.S.L.W. 3274 (U.S. Nov. 13, 1972) (narrow construction of the 1934 Act exclusion of short-term notes).

This Note will speak in terms of the coverage of the 1934 Act, due to the importance of the antifraud protection in its section $10(\mathrm{~b}), 15$ U.S.C. $\S 78 \mathrm{j}(\mathrm{b})(1970)$. However, conclusions about the content of the term "security" may be extended to the other federal securities acts. The same is largely true as to state securities laws, many of which use definitional language similar or identical to that of federal legislation. The similarity of statutory language and the extcnsive reliance of state and federal courts on each other in the construction of this language is reflected in the liberal use this Note makes of state court precedents.

THE FOLLOWING HEREINAFTER CITATIONS ARE USED IN THIS NOTE:

S. Maisel, Financing Real Estate (1965) [hereinafter cited as Maisel];

Coffey, The Econonic Realities of a "Security": Is There a More Meaningful Formula?, 18 W. Res. L. Rev. 367 (1967) [hereinafter cited as Coffey]:

Weil, Land Leasebacks Move Up Fast as Financing Technique, 1 REAL Est. Rev. 65 (Winter, 1972) [hereinafter cited as Weil].

Material filed as part of the record in Huberman v. Denny's Restaurants, Inc., 337 F. Supp. 1249 (N.D. Cal. 1972), is cited as follows:

Complaint and Demand for Jury Trial, filed Aug. 9, 1971 [hereinafter cited as Huberman Complaint];

Defendants' Notice of Motion and Motion to Dismiss Complaint, Statement of Reasons and Memorandum of Points and Authorities, filed Aug. 30, 1971 [hereinafter cited as Defendants' Brief];

Plaintiff's Memorandum of Points and Authorities in Opposition to Defendants' Motion to Dismiss Complaint, filed Sept. 13, 1971 [hereinafter cited as Plaintiff's Brief].

2. See Coffey; Long, An Attempt to Return "Investment Contracts" to the Mainstream of Securities Regulation, 24 OKLA. L. REv. 135 (1971).

3. See Rifkind \& Borton, SEC Registration of Real Estate Interests: An Overview, 27 Bus. LAw. 649 (1972); Note, Cooperative Housing Corporations and the Federal Securities Laws, 71 Colum. L. Rev. 118 (1971). 
date no consideration has been given to whether the securities laws apply to an increasingly important method of financing real estate developments-the sale-leaseback. A recent case, Huberman $v$. Denny's Restaurants, Inc., ${ }^{B}$ suggests that this issue should be explored, as to the sale-leaseback in particular and also as to commercial leasing transactions generally. This Note will analyze the saleleaseback in terms of the various tests which courts have used in applying the federal-law concept of "security." It will also deal with the appropriateness, in policy terms, of including sale-leaseback financing as a security. ${ }^{8}$ Finally, the Note will consider whether certain leasehold transactions other than the pure sale-leaseback are affected by federal securities legislation. ${ }^{9}$

\section{The Sale-Leaseback}

The sale-leaseback is an aptly-named financing method whereby real property is sold to a purchaser who immediately executes a longterm lease to the seller/developer. ${ }^{10}$ The property covered by the transaction may or may not include both underlying land and improvements, but in any case it has been specifically chosen by the seller/developer for long-term use in his own business enterprise. The effect of the sale-leaseback is that the purchaser/lessor supplies long-

4. See Note, Founder Member Contracts Defined as Securities Under Risk-Capital Test, 18 WAYNE L. REV. 1141 (1972).

5. See Comment, The Franchise Agreement: A Security for Purposes of Regulation, 1970 U. ILL. L.F. 130; 24 VAND. L. REV. 638 (1971).

6. 337 F. Supp. 1249 (N.D. Cal. 1972).

7. The Securities Exchange Act of $1934 \S 3(a)(10), 15$ U.S.C. $\S 78 c(a)(10)(1970)$, defines "security" as follows:

The term "security" means any note, stock, treasury stock, bond, debenturc, certificate of interest or participation in any profit-sbaring agreement or in any oil, gas, or other mineral royalty or lease, any collateral-trust certificate, preorganization certificate or subscription, transferable share, investment contract, voting-trust certificate, certificate of deposit for a security, or in general, any instrument commonly known as a "security"; or any certificate of interest or participation in, temporary or interim certificate for, receipt for, or warrant or right to subscribe to or purchase, any of the foregoing; but shall not include currency or any note, draft, bill of excbange, or banker's acceptance which has a maturity at the time of issuance of not exceeding nine months, exclusive of days of grace, or any renewal thereof the maturity of which is likewise limited.

"Investment contract" is the category most frequently used as an open-ended catcb-all, and has been the subject of the bulk of litigation concerning what is meant by "security."

8. See notes 72-101 infra and accompanying text.

9. See notes $112-45$ infra and accompanying text.

10. See MAISel 386; Fink, Joint Ventures, Limited Partierships, Sale-Leaseback and Other Devices: The Developer's Approach (pts. 1-2), 52 CHI. B. REc. 323, 371, at 375 (AprilMay, 1971); Weil 66. 
term capital for the development, a fact reflected in rental payments which typically are set to yield a negotiated rate of interest plus amortization of some or all of the purchase price over the life of the lease. ${ }^{11}$ As opposed to conventional mortgage financing, the saleleaseback offers the developer the advantages of completely deductible rental expenses (rather than a combination of mortgage payments that are deductible only to the extent of their interest element, and depreciation charges that may be low in comparison with the value of the property), ${ }^{12}$ a high ratio of financing to the value of the property,,$^{13}$ certain balance sheet improvements, ${ }^{14}$ and the opportunity to realize some of the capitalized value of the enterprise (since the sale price will often reflect the earning potential of the developed property). ${ }^{15}$ From the viewpoint of the investor, the sale-leaseback offers a rate of return slightly higher than is available on mortgages ${ }^{16}$ possibility of high residual value upon expiration of the lease, and perhaps a degree of upside equity participation through the "percentage lease" device, whereby the lessor receives "overage" rentals which increase with the volume of the development's business. ${ }^{17}$ While status as an owner/lessor may involve tax disadvantages, ${ }^{18}$ these are of

11. MaISEL 387. Another reflection of the long-term financing nature of sale-leasebacks is that prospective purchaser/lessors are quite concerned over the financial rating of their tenants and (in such cases as shopping centers, where the lessee derives his revenues from sub-leases to the actual users of the property) sub-tenants. The applicable rate of interest will reflect these ratings. Id. See R. Ricks, Recent TRends in Institutional Real Estate Investment 26-27 (1964) (insurance companies primarily interested in national-name lessees for saleleaseback transactions).

12. See MaISEL 386-87; Weil 70. This explains why sale-leasebacks have been most frequently used with center-city property, where nondepreciable land is likely to be a large percentage of total value, and with property which has a low basis in the hands of the seller due to rapid depreciation or long ownership.

13. "In typical cases, a company can borrow only two-thirds of the value of a property and must furnish equity for the remainder. In contrast, on a sale, the lender (purchaser) may pay up to 100 per cent of the value." Ma1sel 386. See also Fink, supra note 10, at 376.

14. Sale of heavily depreciated property will yield a capital gain which, less its tax, is an addition to capital. Further, a lease appears on a balance sheet only indirectly as a liability (perhaps as a footnote), while a mortgage is treated as normal debt. See MAISEL 387.

15. See Weil 70-71.

16. The small premium above mortgage rates reflects the increased risk due to the investment being a larger percentage of the value of the underlying security (the purchased property). See MAISEL 387. See note 13 supra.

17. See Maisel 387; R. Ricks, supra note 11, at 37-38, 109: Weil 66. One commentator indicates that in recent years equity participation devices have also become common in mortgage financing. Fink, supra note 10, at 375 .

18. Tax disadvantages to the lessor are the converse of the lessee's tax advantages-rental payments must be taken into income in their entirety, not merely to the extent of the interest 
relatively small importance to the insurance companies and tax exempt organizations which frequently are attracted to saleleasebacks. ${ }^{19}$ In any case, the various advantages to both developers and investors, combined with a growing concern of developers and their individual partners for high leverage and tax shelter, have in recent years made the sale-leaseback a standard real estate financing technique. ${ }^{20}$

Huberman v. Denny's Restaurants, Inc. ${ }^{21}$ concerned a variant of the pure sale-leaseback in that the seller and lessee were not the same party.2 ${ }^{22}$ The property, which was designed for restaurant use, was purchased from a developer subject to a long-term lease to a restaurant chain. ${ }^{23}$ Basically, the developer financed and effected land acquisition and construction of improvements. Upon sale, the developer's interest was largely liquidated, and the investor, Huberman, began supplying the long-term capital needed to secure the improved property for use by the lessee restaurant. In exchange, Huberman was to receive, under the terms of the lease, a minimum annual "rent" equal to 10.4 percent of her investment, plus any amounts by which five percent of the restaurant's gross income exceeded the sum of the minimum rent and other specified amounts. Of course, she also would receive the residual value of the property upon expiration of the lease's term of twenty years (subject to a five-year renewal option) ${ }^{24}$

Huberman brought suit in federal district court seeking to recover under SEC rule $10 b-5^{25}$ and section $10(b)^{26}$ of the Securities Exchange

element. Further, while depreciation charges should eliminate from current income amounts received as recapture of capital invested in improvements, and while accelerated depreciation methods may provide a favorable tax effect in early years, no depreciation charges are available for the portion of the purchase price allocated to raw land.

19. See MaISEL 387; Weil 66. One commentator argues that insurance companies have not been sufficiently aware that their effective tax bracket on investment income is quite low due to the deduction they may take for that portion of such income which is allocated to policy holders. R. Ricks, supra note 11 , at 109 . He suggests that as the importance of this fact is becoming more generally understood, insurance companies are becoming less concerned over the tax disadvantages of sale-leasebacks and more sensitive to such equity aspects as residual values and percentage leases. Id. For the details of this aspect of insurance company taxation, see 8 J. Mertens, Law of Federal Income Taxation $\$ 44 A .05-06$ (1970).

20. See Maisel 385-86; Weil 65, 71 .

21. 337 F. Supp. 1249 (N.D. Cal. 1972).

22. The relevance of this variation is discussed in the text accompanying notes 129-36 infra.

23. 337 F. Supp. at 1250.

24. Id. The opinion is not precisely accurate concerning the terms of the lease. The lease itself was attached as an exhibit to the Huberman Complaint.

25. 17 C.F.R. $\S 240.10 b-5$ (1972).

26. 15 U.S.C. $\& 78 \mathrm{j}(\mathrm{b})(1970)$. 
Act of 1934. She based her claim on allegedly false and misleading representations concerning the restaurant's potential for profitability and growth. ${ }^{27}$ In fact, the business failed. According to the plaintiff's allegations, the defendants knew of economic circumstances making success unlikely, and at the time of the sale had already decided to terminate the business. ${ }^{28}$

The action was brought against the developer, the lessee, the lessee's corporate parent, and various individual agents and servants of the corporate defendants. Allegedly, all of the defendants were under each other's control and all had joined in making the various representations. ${ }^{29}$ The lessee defendants filed a motion to dismiss for lack of subject matter jurisdiction, arguing that the transactions involved no "security" as the term is defined in the Securities Exchange Act. The court denied the motion on the ground that the plaintiff had purchased an "investment contract."

While Huberman is the first case to consider a sale-leaseback transaction in terms of the federal securities acts, ${ }^{30}$ courts have frequently dealt with the general issue of what constitutes an investment contract. ${ }^{31}$ This case law is based on two Supreme Court decisions, $S E C$ v. C.M. Joiner Leasing Corp..$^{32}$ and SEC v. W.J. Howey Co. ${ }^{33}$ In Joiner, an oil land lessee assigned portions of his leasehold, by particular parcels, in order to finance a test well; if the test well were to strike oil, the value of oil rights on each parcel would increase dramatically. The Supreme Court concluded that the parcels were securities, focusing on the fact that the value of the assignments

27. 337 F. Supp. at 1250.

28. Huberman Complaint 5, para. 24.

29. Id. at 5-6, para. 25 .

30. State courts have considered arrangements resembling a sale-leaseback. See Sire Plan Portfolios, Inc. v. Carpentier, 8 Ill. App. 2d 354, I32 N.E.2d 78 (1956). While in legal form the seller retained posscssion of the property under a lease, the arrangement was similar to a management contract-the rent to be paid to the owners (through a trustee) was to be the net income from the property less the seller's management fee.

Another case involving a purported leaseback to the seller even more clearly dealt with a management contract. See Stevens v. Liberty Packing Corp., 111 N.J. Eq. 61, 161 A. 193 (1932), holding that securities were issued by the seller of certain productive property, namely rabbits (at four females for \$175). Under the agreement the seller would retain possession of the property, would receive as his management fee one-half of the product (more rabbits), and would purchase the other half for $\$ 1$ per unit. The investor was thereby enabled "to share in the profits of the rabbit meat industry." Id. at 62,161 A. at 194. Investments were made upon the promise that, "Your cash multiplies as fast as your rabbits . . ." Id.

31. See, e.g., cases cited in notes 40, 49-53 infra.

32. 320 U.S. 344 (1943).

33. 328 U.S. 293 (1946). 
derived not so much from the naked property rights they represented as from their character as participations in the test well. This character, said the Court, was "the thread on which everybody's beads were strung." 34

The Court's emphasis on economic realities was again evident in Howey, which dealt with the sale, for investment purposes, of specific orange trees. While the purchasers could personally care for their trees if they so chose, in practice most purchasers entered into management contracts with a corporation related to the seller. Net proceeds of each harvest were divided by the management company among the various owners on the basis of the quantity of oranges picked from their particular trees. ${ }^{35}$ In ruling that the arrangement involved a security, the Court propounded the test that is now the touchstone for inclusion within the statutory language, "investment contract":

. . a contract, transaction or scheme whereby a person invests his money in a common enterprise and is led to expect profits solely from the efforts of the promoter or a third party . . . . ${ }^{38}$

As in Joiner, the Court considered irrelevant the fact that the shares in the common enterprise were evidenced by ownership of specific assets employed in it. ${ }^{37}$

Huberman approached the investment contract issue in straightforward Howey terms and treated two aspects of the test as meriting discussion: the presence of a common enterprise and the purchaser's reliance "solely" on the efforts of others for her profits. The court found a common enterprise, "as that term is commonly used," in the fact that both the plaintiff and the lessee "were going to benefit from the productive operation of the restaurant," one as owner of a successful business, the other as a landlord with a tenant whose solvency would assure her minimum rental and whose success would increase her rentals. ${ }^{38}$ The court also found the reliance element to be satisfied:

Plaintiff alleges that she bought a pre-packaged investment contract. She was not buying a franchise restaurant to manage and defendants have not claimed that plaintiff ever showed any intention of running the franchise herself. She
34. 320 U.S. at 348.
35. 328 U.S. at $294-96$.
36. Id. at 298-99.
37. Id. at $299,301$.
38. 337 F. Supp. at 1251 . 
was looking solely to the efforts of ... [the] defendants for her profits $\ldots .^{39}$

The court also emphasized the extent to which overage rentals would depend on the efforts of the lessee. The opinion then distinguished two recent cases $^{40}$ in which franchises were held not to be investment contracts-in those cases the purchaser/franchisee had managerial powers and operational responsibilities that were entirely absent from the Huberman lease agreement. ${ }^{41}$

\section{The Sale-Leaseback and Prevailing Case Law}

The sale-leaseback situation readily satisfies the "profits solely from the efforts of [others]" element of the Howey test, for quite clearly the owner/lessor is a passive investor as to the lessee enterprise (albeit should that enterprise remove itself from the property, his profits would then depend on his own efforts). ${ }^{42}$ However, a common enterprise is not so clearly present in the sale-leaseback arrangement. This aspect of the test was not explained in Howey and its vagueness has led several commentators to criticize it as one of the primary weaknesses of the Howey formulation. ${ }^{43}$ Two meanings are possible-a commonality of enterprise between at least one investor and a promoter, or a commonality of enterprise among a number of investors. ${ }^{44}$ The latter formulation is more consistent with the popular notion that a security represents one of many similar units of interest in an enterprise, and seems to be the approach which at least one court has recently adopted. ${ }^{45}$ However, to define a common enterprise

39. Id.

40. Chapman v. Rudd Paint \& Varnish Co., 409 F.2d 635 (9th Cir. 1969); Mr. Steak, Inc. v. River City Steak, Inc., 324 F. Supp. 640 (D. Colo. 1970), aff d, 460 F.2d 666 (10th Cir. 1972).

4I. 337 F. Supp. at 1249-51.

42. This part of the Howey test has been liberally intcrpreted by some courts. See, e.g., cases cited in notes $49-53$ infra.

43. See Coffey, 374-75; Long, supra note 2, at 143-44; Note, supra note 4, at 1148-49.

44. It has been pointed out that "common enterprise" involves ambiguity not only as to the number of investors required, but also as to the type of interest in the cnterprise that the investor must have-that is, must it be an equity interest, depending on profitability for its value, or need it be only the interest of a fixed-sum obligor whose concern is mereiy that the enterprise remain soivent? Coffey 374-75 n.41. Since the percentage rental term does provide a limited cquity interest in most sale-leasebacks, see notes 17 supra and 121 infra and accompanying text, this issue need not be confronted at this time. The effect of eliminating this limited equity interest will be discussed below in the course of considering variations on the typical saleleaseback. See notes 113-28 infra and accompanying text.

45. See Milnarik v. M-S Commodities, inc., 457 F.2d 274 (7th Cir.), cert. denied, 93 S. Ct. 113 (1972), in which a discretionary commodities trading account was held to involve only 
in this manner would make little sense in terms of results-not only would it eliminate security status when there is only one investor rather than two, but it would produce this result as to only one of the many categories of financial arrangements that are legislativelydefined to be securities. ${ }^{46}$ Further, such a restrictive interpretation is not required for the common enterprise concept to play its most readily-defensible role: that of distinguishing between those passive investors who are seeking profits from general market appreciation or from the independent efforts of unrelated third parties, such as developers of adjoining real estate, and those seeking profits from the efforts of persons in some way directly related to the enterprise in which they have invested. ${ }^{47}$

A construction of "common enterprise" that permits its being found in a sale-leaseback, while not a startling result, ${ }^{48}$ is nonetheless more expansive than is required by either the Howey language or its application in subsequent cases. Such a liberal constructional preference is quite consistent not only with the emphasis in Howey and Joiner on broad construction of remedial statutes, but also with recent judicial application of other elements of the test. Of particular note is the dilution of the requirement that profits be expected solely from the efforts of others. While some recent cases literally apply the word "solely," 49 courts have been increasingly willing to inquire whether the investor's role in the enterprise is significant in terms of its ultimate success ${ }^{50}$ and whether the investor is sufficiently sophisti-

an agent-principal relationship where there was no pooling of the funds of the various investors relying on the defendant's trading efforts.

46. See note 7 supra.

47. This view of common enterprise is that adopted by Professor Loss. See 1 L. Loss, Securities Regulation 491 (2d ed. 1961). See also Long, supra note 2, at 162-63, 175.

48. The Attorney General of California has endorsed the view that a common enterprise is present even where the only persons participating in a common pool are a single investor and the promoter. See 49 OP. CaL. ATTY. Gen. 124, 126-27 (1967) (Op. No. 66-284), reprinted in, [1954-1971 Transfer Binder] Blue SKY L. ReP. If 70,747, at 66,641-42 (1967).

49. Chapman v. Rudd Paint \& Varnish Co., 409 F.2d 635 (9th Cir. 1969) (arguably dictum, for the "investor" was very heavily involved as a salesman); Gallion v. Alabama Mkt. Centers, Inc., 282 Ala. 679, 213 So.2d 841 (1968) (founder-member contracts); Georgia Mkt. Centers, Inc. v. Fortson, 225 Ga. 854, 171 S.E.2d 620 (1969) (founder-member contracts); Goldsmith v. American Food Serv., Inc., 123 Ga. App. 353, 181 S.E.2d 95 (1971) (franchise); Koscot Interplanetary, Inc. v. King, 452 S.W.2d 531 (Tex. Civ. App. 1970) (multi-tier distribution scheme).

50. Venture Inv. Co. v. Schaefer, 3 Blue Sky L. Rep. If 71,031 (D. Colo., June 16, 1972); D.M.C. of Colo., Inc. v. Hays, [1954-1971 Transfer Binder] BLUE SKY L. REP. If 70,897, at 67,043 (Colo. Dist. Ct. 1971). See also Davenport v. United States, 260 F.2d 591 (9th Cir. 1958) (employment in a non-managerial capacity insufficient to prevent finding of an investment 
cated that he need not heavily rely on the lessee's representations and superior knowledge. ${ }^{51}$ Thus, a security has been found even though the purchaser's profits were keyed to his own efforts to attract prospects to inspirational sales meetings ${ }^{52}$ or to solicit members and other founder/members for a member-only department store. ${ }^{53}$ In both of these situations, much of the investor's return depended on sales actually being made to his prospects, and the actual selling was controlled by the promoter. In effect, some courts have changed "solely" to "substantially" in order to assure that the securities laws are responsive to economic realities and are not undermined by schemes requiring insignificant investor efforts. ${ }^{54}$

Similar judicial unwillingness to be closely bound by an overlyfine applicaton of the Howey language is also reflected in rccent decisions dealing with other aspects of the Howey test. ${ }^{55}$ While these cases, and those modifying the "solely" language, are not uniformly accepted ${ }^{56}$ they do indicate a substantial likelihood that many courts

contract); Polikoff v. Levy, 55 Ill. App. 2d 229, 204 N.E.2d 807 (1965); Bruner v. State, 463 S.W.2d 205 (Tex. Crim. App. 1970) (no security found because investor's efforts were more than "minimal"); 49 Op. CAL. ATTY. GeN. 124, 126 (1967) (Op. No. 66-284), reprinted in, [1954-1971 Transfer Binder] BLUE SKY L. ReP. If 70,747, at 66,641 (1967).

51. Beefy Trail, Inc. v. Beefy King Int'l, Inc., 348 F. Supp. 799 (M.D. Fla. 1972) (no security found where franchisee was an experienced businessman who actively participated in franchise operations).

52. SEC v. Glenn W. Turner Enterprises, 348 F. Supp. 766 (D. Ore. 1972).

53. D.M.C. of Colo., Inc. v. Hays, [1954-1971 Transfer Binder] BluE SKY L. REP. I 70,897 (Colo. Dist. Ct. 1971); State v. Hawaii Mkt. Center, Inc., [1954-1971 Transfer Binder] Blue SkY L. ReP. If 70,880 (Hawaii Cir. Ct. 1970), aff d, 52 Hawaii 642, 485 P.2d 105 (1971).

Each of these courts also endorsed the view that profits would arise solely from the efforts of others, within the meaning of Howey, if an investor's profits could easily be eliminated by the efforts of others (through, for example, failing to open the planned membership department store). D.M.C. of Colo., Inc. v. Hays, supra at 67,042; State v. Hawaii Mkt. Center, Inc., supra at 67,007-08. A similar position was adopted in Venture Inv. Co. v. Schaefer, 3 BLUE SKY L. REP. II 71,031 (D. Colo., June 16, 1972).

54. D.M.C. of Colo., Inc. v. Hayes, [1954-1971 Transfer Binder] Blue Sky L. ReP. If 70,897, at 67,042 (Colo. Dist. Ct. 1971); State v. Hawaii Mkt. Center, Inc., [1954-1971 Transfer Binder] BLue SKY L. ReP. If 70,880, at 67,007 (Hawaii Cir. Ct. 1970), aff d, 52 Hawaii 642, 485 P.2d 105 (1971).

55. See Continental Marketing Corp. v. SEC, 387 F.2d 466 (10th Cir. 1967) (reliance need not be on the efforts of the seller or a party controlled by the seller); Roe v. United States, 287 F.2d 435 (5th Cir. 1961) (as in Continental Marketing); SEC v. Lake Havasu Estates, 340 F. Supp. 1318 (D. Minn. 1972) (common enterprise found where investor purchases the obligation of a third party, but seller guarantees the obligation and is responsible for its collection). Cf. Johnson v. Arthur Espey, Shearson, Hammill \& Co., 341 F. Supp. 764 (S.D.N.Y. 1972) (discretionary commodities trading account held to be an investment contract; no discussion of Howey).

56. See Milnarik v. M-S Commodities, Inc., 457 F.2d 274 (7th Cir.), cert. denied, 93 S. Ct. 113 (1972). See also cases cited in note 49 supra. 
would adopt the broader, yet nonetheless natural, construction of the common enterprise concept that brings sale-leasebacks within the securities laws.

\section{The Sale-Leaseback and Risk Capital}

In addition to the courts which have been applying a loose version of the Howey test, other courts are making more substantial departures from Howey by developing a new approach to the "investment contract." The so-called risk capital test originated in a 1961 decision of the California Supreme Court, Silver Hills Country Club v. Sobieski ${ }^{57}$ As generally understood, the test involves an inquiry into whether an investor is supplying a substantial portion of the capital required for the operation of the enterprise and subject to the risk of its failure. This approach facilitates greater attention to the realities of the relationships among the parties and the enterprise, especially since it frees the courts from focusing on the specifie wording of the Howey test. The common enterprise element of Howey is eliminated, and the court need not look for "profits"; rather, it concerns itself with whether the investment has been made with an expectation of receiving some valuable benefit. ${ }^{58}$ Of particular importance is the elimination of the requirement that the investor rely "solely" on the efforts of others..$^{59}$ Instead, the risk capital courts inquire into whether the investor is an active participant in the enterprise, and whether he is sufficiently familiar with it to be reasonably independent of the seller's representations. ${ }^{60}$ The result is that securities can readily be found despite nominal or non-managerial investor involvement under, for example, some founder/member contracts, ${ }^{61}$ pyramid

57. 55 Cal. $2 \mathrm{~d} 811,361$ P.2d 906, 13 Cal. Rptr. 186 (1961). The significance of supplying risk capital was not entirely new with the Silver Hills decision. The general concept appears in occasional pre-Howey cases, albeit not in a concise form. See, e.g., Brownie Oil Co. v. Railroad Comm'r, 207 Wis. 88, 90, 240 N.W. 827, 829 (1932).

58. This means, for example, that a security can be found where an investment is made not for a monetary return, but rather for a valuable benefit in the form of rights to use club facilities. See Silver Hills Country Club v. Sobieski, 55 Cal. 2d 811, 361 P.2d 906, 13 Cal. Rptr. 186 (1961). For other interpretative problems involved with the term "profits," see note 125 infra.

59. For a discussion of the interpretative problems posed by this Howey requirement, see notes $49-54$ supra and accompanying text.

60. SEC v. Glenn W. Turner Enterprises, Inc., 348 F. Supp. 766 (D. Ore. 1972); Mr. Steak, Inc. v. River City Steak, Inc., 324 F. Supp. 640, 646-47 (D. Colo. 1970), aff d, 460 F.2d 666 (10th Cir. 1972); State v. Hawaii Mkt. Center, Inc., 52 Hawaii 642, 485 P.2d 105, 109 (1971), aff $g$ [1954-1971 Transfer Binder] BLve SKY L. REP II 70,880 (Hawaii Cir. Ct. 1970).

61. See State v. Hawaii Mkt. Center, Inc., 52 Hawaii 642, 485 P.2d 105 (1971), aff g [1954- 
schemes, ${ }^{62}$ and franchise agreements. ${ }^{63}$

The effect of applying the risk capital test to sale-leasebacks is not entirely clear. While the approach avoids the ambiguities of the common enterprise requirement, it does raise the issue of whether the purchaser/lessor's capital is subjected to "risk." Arguably it is not, inasmuch as it is secured by title to valuable tangible property. In actual risk capital cases, on the other hand, the likelihood of complete loss of the investment has been fairly high, with the investor receiving, for example, rights to use club facilities, if and when built, ${ }^{64}$ rights to operate a franchise should the franchisor successfully develop his product, ${ }^{65}$ and rights to commissions should the promoter open a store and make sales to prospects supplied by a founder-member ${ }^{66}$ It is quite possible that courts will restrict the risk capital test to this type of high-risk case, despite strong encouragement to the contrary by some observers. ${ }^{67}$ Indeed, one court has explicitly adopted the position that the risk capital test requires "exceptionally high risk" and not the ordinary "insubstantial risk of doing business." ${ }^{68}$ Such an attitude would likely exclude the sale-leaseback investor who, in any case, would retain improved real property. ${ }^{69}$

This is not to say, however, that risk capital courts would consider sale-leasebacks to be outside the securities acts, for even those courts

1971 Transfer Binder] Blue Sky L. ReP 7 70,880 (Hawaii Cir. Ct. 1970) (see notes 53-54 supra and accompanying text for a discussion of the relaxed Howey test applied by the lower court).

62. See SEC v. Glenn W. Turner Enterprises, Inc., 348 F. Supp. 766 (D. Ore. 1972). The use in this case of the risk capital test is somewhat unusual. It was treated as a key to whether an arrangement involved an "instrument commonly known as a "security," "whereas other cases have used the risk capital test as an approach to the "investment contract."

63. See Venture Inv. Co. v. Schaefer, 3 Blue Sky L. REP. I 71,031 (D. Colo., June 16, 1972). Cf. State ex rel. Healy v. Consumer Business Sys., Inc., __ Ore. App. $\longrightarrow 482$ P.2d 549 (1971). In this case the court specifically found that investor involvement prevented tbe agreement from satisfying the Howey test. Id. at $\longrightarrow, 482$ P.2d at 552.

64. Silver Hills Country Club v. Sobieski, 55 Cal. 2d 811, 361 P.2d 906, 13 Cal. Rptr. 186 (1961).

65. See Venture Inv. Co. v. Schaefer, 3 Blue SKY L. ReP. \ 71,031 (D. Colo., June 16, 1972). State ex rel. Healy v. Consumer Business Sys., Inc., __ Ore. App. 482 P.2d 549 555 (1971).

66. State v. Hawaii Mkt. Center, Inc., 52 Hawaii 642, 485 P.2d 105 (1971), affg [19541971 Transfer Binder] Blue Sky L. REP. I 70,880 (Hawaii Cir. Ct. 1970).

67. Note, supra note 4. See also Coffey 381-96. But see 24 VAND. L. REv. 638 (1971).

68. Mr. Stcak, Inc. v. River City Steak, Inc., 324 F. Supp. 640, 647 (D. Colo. 1970), affd, 460 F.2d 666 (10th Cir. 1972).

69. In addition to the protection created by ownership of the property, Huberman's risk was also reduced by rental payments which were guaranteed for the first seven years of the twenty-year term by the lessee's publicly-traded parent. 
which most narrowly apply the test do not treat it as the exclusive test for an investment contract. Rather, they use it as a safety valve to provide securities legislation protection to high-risk investors who are not protected under Howey. ${ }^{70}$ Whether the risk capital courts would hold sale-leasebacks to be within Howey is a different issue. However, since they obviously are unwilling to be bound by restrictivc application of the conventional test, it seems likely that they would accept the construction of "common enterprise" which qualifies the sale-leaseback as a security under Howey. ${ }^{71}$

\section{The Sale-Leaseback and Securities Regulation Policy}

The foregoing discussion indicates that many courts will, if confronted with the issue, find that sale-lcasebacks are subject to federal securities legislation. It remains to be considered whether such a result conforms with the policies underlying that legislation. Several approaches to this issue will be developed. First, the appropriateness of including sale-leasebacks as securities will be considered by means of an analogy to a similar financial transaction which clearly involves a security. ${ }^{72}$ Second, the issue will be considered in terms of a test which one commentator has proposed as the key to defining not only investment contracts but all other forms of securities as well $;^{73}$ this test has the advantage of directly focusing on the particular elements of a financial transaction which are thought to justify special protec-

70. Mr. Steak, Inc. v. River City Steak, Inc., 324 F. Supp. 640, 646 (D. Colo. 1970), affd, 460 F.2d 666 (10th Cir. 1972); State ex rel. Healy v. Consumer Business Sys., Inc., - Ore. App. — 482 P.2d 549 (1971). Should any court treat the risk capital approach as its exclusivc investment contract test, consistency with Howey would seem to require a relaxed concept of risk that would reach a sale-leaseback. This approach would be required because the salcleaseback involves the same risk as was present in Howey, namely, that of purchasing investment property at a price which is based on the seller's claims as to its profitability under his own, or a third party's, management and control.

71. See notes 43-47 supra and accompanying text for a discussion of the construction of "common enterprise" that is needed to qualify the typical sale-leaseback as a Howey security.

72. See notes 76-81 infra and accompanying text. That the other categories of the statutory definition may be considered in determining the scope of the "investment contract" language is supported not only by the argument that the securities laws are aimed at a general evil, not merely specific and arbitrary manifestations of the evil, but also by the Supreme Court's use of this method in SEC v. United Benefit Life 1ns. Co., 387 U.S. 202 (1967):

Contracts such as the [one at bar] offer important competition to mutual funds . . . and are pitched to the same consumer interest in growth through professionally managed investment. 1t seems eminently fair that a purchaser of such a plan be afforded the same advantages of disclosure which inure to a mutual fund purchaser . . . Id. at 211 .

73. Coffey. 
tion against fraud..$^{74}$ Third, the issue will be approached in terms of the Supreme Court's broad-brush concept of the role and purpose of the federal securities laws. ${ }^{75}$

Analogy to Other Securities. The legislative definition of "security" enumerates a number of particular instruments and encompasses those commonly used to finance business activity. The listing includes not only equity instruments but also fixed-obligation instruments, both secured and unsecured, such as "any note, . . . bond, [or] debenture ...."76 The fact that a mortgage is covered, as a "note" or "evidence of indebtedness"77 is especially relevant, for in terms of risk and economic function a mortgage is quite similar to a sale-leaseback. ${ }^{78}$ The essential characteristic of a commercial mortgage is that it parlays the resale value of specific property into financing for the use of that property, and in this respect the sale-leaseback is similar. The two are also similar from the standpoint of the mortgagee or lessor should the promoter default on his obligations: each is left with the specific property in lieu of the regular, long-term, fixed income for which he made his investment; in addition, in each case the improvements are likely to be specialized in nature and of reduced value when used other than in the business for which they were designed and in which the promoter has failed. Finally, mortgages and sale-leasebacks are viewed by developers and investors as related financing methods carrying similar interest rates, ${ }^{79}$ and in many instances the choice of one or the other turns on tax advantages to the developer/lessee rather than on differences of any significance as to whether a security is involved. ${ }^{80}$

74. See notes 82-92 infra and accompanying text.

75. See notes 93-101 infra and accompanying text.

76. See note 7 supra.

77. Rifkind \& Borton, supra note 3, at 660 . Limited exemptions from the securities acts for mortgage transactions are found in SEC rule 15a-1, 17 C.F.R. $\S 240.15 a-1$ (1972), and SEC rule 234, id. \& 230.234 (1972).

78. This similarity can be so pronounced that the "seller/lessee" may be deemed, for purposes of deducting his rental payments, not to have sold the property at all, such that the transaction constituted merely the extension of a mortgage loan. In such a case, the "seller/lessee" may deduct only the interest portion of the "rental" payments. The leading case on this subjeet involved a lease term of ten years (with 15 years of renewal options), rent equal to 5 percent interest plus amortization of the purchase price over the initial term, and a repurchase option at a very low price. See Paul W. Frenzel, 32 P-H ТAх Ст. Мем. II 63,276 (1963).

79. MAISEL 386-87; Fink, supra note 10, at 375-76. In the case of sale-leasebacks the applicable interest rate is of course translated into dollar-value "rental" payments. See note 11 supra and aceompanying text. See also Weil 66, 70.

80. See note 12 supra and accompanying text. 
Of course, sale-leasebacks do differ from mortgages in ways that are relevant to whether a security is involved. A sale-leaseback gives the investor a long-run residual interest; it is more likely to provide him with participation in the lessee's success, through percentage rental clauses; and it may be junior to mortgage financing if the property was purchased subject to a mortgage.81 These differences, however, do not remove sale-leasebacks from the class of financing methods that are defined as securities; rather they render the saleleaseback evcn more appropriate for security status and its antifraud protection. Each of these differences makes the transaction more akin to equity financing but none increases the investor's participation in or control over the operations of the enterprise. While in form a sale of real property, the sale-leaseback is, as a matter of economic and financial reality, mortgage financing with modifications which give it, in a limited way, the risks and potential earnings of an equity interest. So characterized, the sale-leaseback is appropriately included in that statutorily-described class of financial transactions which encompasses mortgages, common stock, and such limitedequity instruments as convertible debentures and preferred stock.

The Coffey Approach. Professor Coffey advocates a policyoriented test of whether a particular transaction should be considered a security. He argues that the "security" concept should reach transactions involving a substantial possibility of fraud; it is the danger of fraud which, for Coffey, justifies the special antifraud causes of action, procedures, and remedies provided by federal securities legislation..$^{82}$ Thus, he seeks to identify characteristics of financial transactions which make fraud likely. The result is an elaborate version of the risk capital test, but its concept of risk is much less restrictive than that generally employed by risk capital courts. For Coffey, a security is (1) a transaction (which term encompasses the collective effect of multiple related events, such as a sale followed by a separate leaseback) $)^{83}$ in which (2) an investor contributes to an enterprise something of value which (3) is subjected to a risk of loss, ${ }^{84}$ where (4)

81. Weil 66. See also Fink, supra note 10, at 376.

82. Coffey 371-73. Since all securities are subject to antifraud provisions, but only certain classes of publicly-issued securities are subject to the registration requirements of the securities acts, it is proper to focus on the need for antifraud protection in defining a security. For a discussion of the ways in which the securities statutes relax the procedural and substantive requirements for common-law and equitable fraud actions, see $3 \mathrm{~L}$. Loss, supra note 47 , at $1421-44,1763-97$.

83. Coffey $377-80$.

84. Id. at $377,380-96$. 
the investor has little familiarity with or control over the enterprise, ${ }^{85}$ and where (5) he has a reasonable expectation of receiving some form of valuable benefit in excess of his original contribution..$^{86}$

Since the sale-leaseback investor typically does not participate in the enterprise, and since he clearly invests with an expectation of net benefit, the key to applying Coffey's test to a sale-leaseback lies in the meaning of "risk." As already mentioned, Coffey's concept of risk is much broader than that used by some courts, ${ }^{87}$ as indeed it must be if the test is to serve as a single standard for identifying all forms of securities. For Coffey, any significant risk to the initial investment is sufficient to invoke the antifraud protection of the securities laws if the transaction otherwise qualifies ${ }^{88} \mathrm{He}$ includes not only the risks attendant to equity interests, but also the unsecured creditor's risk that equity and junior indebtedness will be eroded, as well as the secured creditor's risk that unsuccessful operation of the enterprise will "take its toll of the property securing the debt." ${ }^{89}$ In addition, he specifically asserts that a buyer incurs sufficiently significant risk when he purchases property which is immediately recommitted to an enterprise. ${ }^{90}$ While the last category appears to encompass the sale-leaseback, Coffey does not specifically mention this financing method; in his examples, the investor's return is both variable and highly dependent upon the success of the enterprise in employing the property-such as contracts for management, servicing, or resale by the enterprise. ${ }^{91}$ Thus, it is arguable that sale-leasebacks are excluded because of their fixed-return elements. However, one must be aware that Coffey's basic inquiry is not whether a transaction fits one of his specific categories, but rather is whether the investor's contribution is subject to any actual risk of loss. Clearly, the sale-

85. Id. at $377,396-98$.

86. Id. at $377,398-403$. The principal ways in which this test differs from Howey are its concentration on risk of loss of the original investment, its dc-emphasis of the importance of "profits," its clarification of "profits" as "valuable benefits," and its elimination of the common enterprise requircment.

87. See notes 64-68 supra and accompanying text.

88. Coffey $384-85$.

89. Id, at $385-86$. A debt that is secured by rcal property is nonetheless subjcct to significant risks at the hands of a failing enterprise. In particular, repairs and maintcnance are likely to have been ignored or given short shrift, and it is possible that the secured debtor would take the property subject to liens for unpaid taxes and utilities. In addition, account must be taken of the expense and delay rcquired to obtain a purchaser or tenant for the property.

90. Id. at 386-90.

91. Id. at $386 \mathrm{nn} .89-90,401 \mathrm{n} .147$. 
lease-back carries at least the risk inherent in secured debt, ${ }^{92}$ especially since it often involves specialized property, the value of which depends on profitable employment by the enterprise. In sum, it seems reasonably clear that a sale-leaseback qualifies under Coffey's test as a transaction which should be accorded the special protections of the securities acts.

Supreme Court Interpretation of Securities Legislation Policy. A final approach to the question of whether sale-leasebacks belong in the category of "investment contracts" involves a consideration of the policies which the Supreme Court finds embodied in federal securities legislation. Howey and other Supreme Court "investment contract" cases ${ }^{93}$ contain at least two policy themes of particular importance to the sale-leaseback question: that the statutory policy is one of "affording broad protection to investors," primary policy is to be implemented with regard to a transaction's economic substance, not to the legal form in which it is cast.

Although the statutory purpose is said to be protection of particular people known as "investors," the statutory protections are triggered by the presence of something other than an investor, namely a "security." This leads to the question whether an "investor" is protected because he buys a statutorily defined "security," or whether a "security" is something that is subject to the statutes because it is purchased by persons who are, within the contemplation of the statutes, "investors." Clearly, the typical judicial approach is the former, under which the inquiry is whether a transaction involves one of the specified instruments. However, in determining the nature of the instrument known as an "investment contract," the Supreme Court in Howey considered whether the purchaser was a statutorily-protected "investor" and also indicated the characteristics of such a person. The Court stated that the term "security" embodies a "flexible rather than a static principle, one that is capable of adaptation to meet the countless and variable schemes devised by those who seek the use of the money of others on the promise of profits." ${ }^{95}$ The Court added:

Thus all the elements of a profit-seeking business venture are present here. The

92. See note 89 supra and accompanying text.

93. See Tcherepnin v. Knight, 389 U.S. 332 (1967); SEC v. United Benefit Life Ins. Co., 387 U.S. 202 (1967); SEC v. C.M. Joiner Leasing Corp., 320 U.S. 344 (1943).

94. 328 U.S. at 301.

95. Id. at 299 (emphasis added). This language was repeated in Tcherepnin v. Knight, 389 U.S. 332,338 (1967). 
investors provide the capital and share in the earnings and profits; the promoters manage, control and operate the enterprise. It follows that the arrangements whereby the investors' interests are made manifest involve investment contracts . . . . 96

In short, Howey tells us that the definition of "security" will be expanded to protect those who, upon the expectation of profit, provide capital financing for profit-seeking enterprises belonging to others. ${ }^{97}$

The Supreme Court has also made it clear that in determining the breadth of securities act protection, the inquiry is to be focused on economic reality rather than legal form. In Howey the Court found a security even though the documents consisted of land sale contracts, warranty deeds and service contracts, while in Joiner documentation in the form of oil lease assignments did not remove the scheme from securities law coverage. Emphasizing the importance of the substance of a transaction, the Howey Court stated that the "arrangements . . . involve investment contracts, regardless of the legal terminology in which such contracts are clothed." ${ }^{98}$ Similar statements may be found in all Supreme Court investment contract cases. ${ }^{99}$

To summarize this discussion of the policy basis of the Howey test, the broad protection of the securities laws is not restricted to a closed set of transactions specified by either legislation or judicial decision. Rather, the protection extends to any transaction, whatever its name and secondary traits, in which the lure of profit is used to obtain financing. When these characteristics are coupled with the fact that "it is immaterial whether the enterprise is speculative or nonspeculative," 100 it becomes apparent that even if a sale-leaseback does

96. 328 U.S. at 300 (emphasis added).

97. This statement is of course subject to such statutorily-specified exceptions as that for obligations issued or guaranteed by a state. Securities Exchange Act of 1934 \&3(a)(12), 15 U.S.C. $\S 78 \mathrm{c}(\mathrm{a})(12)(1970)$.

98. 328 U.S. at 300 . Further, the Court noted: "Form was disregarded for substance and emphasis was placed on economic reality." Id. at 298 (commenting favorably on state-law cases).

99. See, e.g., Tcherepnin v. Knight, 389 U.S. 332 (1967) ("Finally, we are reminded that, in searching for the meaning and scope of the word 'security' in the Act, form should be disregarded for substance and the emphasis should be on economic reality." Id. at 336); SEC v. United Benefit Life Ins. Co., 387 U.S. 202 (1967) (The test is not the nature (realty or personalty) of the assets supporting a particular document. "The test rather is what character the instrument is given in commerce by the terms of the offer, the plan of distribution and the economic inducements held out to the prospect." Id. at 211, quoting SEC v. C.M. Joiner Leasing Corp., 320 U.S. 344, 352-53 (1943)).

100. Tcherepnin v. Knight, 389 U.S. 332, 345 (1967), quoting SEC v. W.J. Howey Co., 328 U.S. 293, 301 (1946). 
not fit neatly within the wording of the Howey test, it must be included as an investment contract. Otherwise, the Supreme Court's underlying concept of the purpose and reach of securities legislation will not be given effect; as has been discussed above, ${ }^{101}$ in economic reality the sale-leaseback is a transaction in which the seller/lessee obtains long-term financing from an investor who receives promises or representations of security and profit.

\section{The Effect of Securities Regulation on Sale-Leasebacks}

This Note has concluded that courts in the future are likely to treat sale-leasebacks as securities. However, such treatment is unlikely to have a burdensome, or even noticeable, effect on developers who deal solely with institutional investors. First, sale-leasebacks with such investors qualify for the private placement exemption from registration. ${ }^{102}$ Second, an institutional investor's standard investigatory procedures will normally elicit and verify the information needed for a responsible investment decision. ${ }^{103}$ Thus, even if the lessee should default, the circumstances are not likely to support a claim of fraud. Finally, such investors are normally well-protected by extensive, carefully drafted contractual provisions. ${ }^{104}$

101. For a discussion of the nature of the sale-leaseback as a financing technique, see notes 10-20, 77-81 supra and accompanying text.

102. Securities Act of $1933 \S 4(2), 15$ U.S.C. $\$ 77 \mathrm{~d}(2)$ (1970). While one hesitates to categorically state that any such transaction qualifies for the private offering excmption, see note 107 infra and accompanying text, the exemption has little meaning if it does not reach sales to institutional investors. See The Value Line Fund, Inc. v. Marcus, [1964-1966 Transfer Binder] CCH FED. SEC. L. REP. I 91,523, at 94,970-71 (S.D.N.Y. 1965).

103. The institutional invcstor's ability to obtain necessary information was recognized in The Value Line Fund, Inc. v. Marcus, [1964-1966 Transfer Binderl CCH Fed. Sec. L. REP. If 91,523, at 94,970 (S.D.N.Y. 1965):

The [mutual] funds . . . were sophisticated, knowledgeable, experienced institutional investors with great resources, and plainly were "able to fend for themselves." All of them . . . clearly would have had access to the kind of information which a registration statement would have disclosed, as well as the ability and opportunity to investigate [the issuer], intcrogate [the seller], and analyze the securities. ...

[T] he offerees possessed enough sophistication to demand, and enough leverage at the bargaining table to receive, all information relevant to make a fully informed decision on whether or not to buy [the] stock.

104. The low likelihood of fraud being practiced in isolated transactions with sophisticatcd investors has led Profcssor Coffey to argue that such transactions should be entirely excmpt from the securities laws and not merely from registration. Coffey 407-11. He acknowledges that the statutes and cases provide little support for this position, but urges that considerations of administrative and judicial economy call for cutting of application of the statutes short of thousands of transactions in which there is little need for the statutory protections. Id. This argument fails to recognize that no administrative or judicial burden is created unless an 
As to individual investors, on the other hand, there is a somewhat greater basis for the fears expressed by counsel for the Huberman defendants that a decision adverse to them would "upset innumerable existing leases, [and] also swamp the Securities and Exchange Commission." 105 In the first place, the individual investor's frequent lack of sophistication and investigatory resources creates a situation in which deception can readily occur, so that $10 \mathrm{~b}-5$ actions involving sale-leasebacks can be expected in the future. In addition, a more serious threat to sale-leaseback financing schemes may be available to individual investors: a suit for rescission under section 12 of the 1933 Act, ${ }^{106}$ grounded on the developer's having made a publie offering of an unregistered security. Whether the private offering exemption from registration is available in sale-leasebacks with individuals is uncertain, even when only one investor buys the entire offering. Some recent cases have indicated that the exemption is available only when the offerees have a high degree of access to information about the enterprise. ${ }^{107}$ Thus, eligibility for private placement exemptions could be particularly troublesome when, as in Huberman, saleleasebacks are sold through real estate agents. Not only might realtors make a large number of offers, but their offerees are likely to have neither sophistication nor significant access to corporate information.

Although the facts in Huberman make it apparent that some individuals purchase sale-leasebacks, most developers probably deal with institutions. Real estate literature treats the sale-leaseback as the exclusive domain of institutional investors, giving no indication whatsoever that sale-leasebacks, or participations in them, are considered appropriate for sale to individuals. ${ }^{108}$ This omission is not surprising

investor seeks relief from alleged fraud, and that the protection is in fact needed in those isolated cases of fraud on sophisticated investors.

105. Defendants' Brief at 6.

106. Securities Act of $1933 \S 12,15$ U.S.C. $\$ 77 l$ (1970). A rescission suit is more scrious than a 10b-5 action for two reasons. First, the recovery, in terms of dollars, is greater, for the rescinding purchaser gets his purchase price plus interest, whereas the successful $10 \mathrm{~b}-5$ plaintiff retains the security and gets only the difference between its fair market value and the purchase price. Second, the burden of proof of fraud and damage in a 10b-5 action is on the plaintiff. Rescission, on the other hand, is granted virtually automatically upon the issuer's failure to carry the burden of proving his eligibility for an exemption from registration. See, e.g., Henderson v. Hayden-Stone, Inc., 461 F.2d 1069, 1072 (5th Cir. 1972). Cf. A.C. Frost \& Co. v. Coeur D'Alcne Mines Corp., 312 U.S. 38, 43 n.2 (1941).

107. SEC v. Continental Tobacco Co. of S.C., 463 F.2d 137, 159 (5th Cir. 1972); Henderson v. Hayden-Stone, Inc., 461 F.2d 1069, 1072 (5th Cir. 1972).

108. See generally MAISEL 386-87; R. Ricks, supra note 11; Fink, supra note 10; Weil. 
since only institutional investors are not significantly affected by the periodic return being treated as rent and thus entirely includible in taxable income. ${ }^{109}$ Further, the sale-leaseback does not provide the fiow-through of enterprise tax losses that has in recent years made limited partnerships popular with individual investors. Such tax considerations suggest that individuals are more likely to invest in real estate developments as limited partners of the developer/lessee than as purchaser/lessors. ${ }^{110}$

To summarize, even if courts uniformly hold sale-leasebacks to be securities, the securities laws will continue to have a very limited impact in transactions involving the primary sale-leaseback purchaser-the institutional investor. However, security status could be quite significant to the extent sale-leasebacks involve individual investors, especially when the requirements of the private offering exemption are not met. ${ }^{111}$

\section{VARIATIONS ON THE SALE-LEaseback}

The foregoing discussion has focused on the typical commercial sale-leaseback - that is, a purchase accompanied by execution of a net, ${ }^{112}$ percentage, long-term lease to the seller or to a party related to him. This Note will now inquire into the effects of varying the transaction in certain respects. Consideration will be given to saleleasebacks without a percentage rent provision, to transactions in which the lease is with a party unrelated to the seller, and to transactions involving a lease and nothing more.

\section{Fixed-Rental Sale-Leasebacks}

If the Huberman lease had provided for a flat rental, with the lessor receiving no overage for increased lessee sales, the case might have had a different resolution. As mentioned above, ${ }^{113}$ the court

109. See MaISel 386-87. For a discussion of the tax effects of salc-leasebacks, see notes $12,18-19$ supra and accompanying text.

110. See Weil 71.

111. Throughout this discussion it has been assumcd that salc-leaseback investors will not be troubled by the SEC rule 144 restrictions on resale of unregistered securities. The rule is broadly worded and in fact will mean that the concerned investor cannot obtain an SEC noaction letter assuring that he is considcred exempt from the prohibitions against sale of unregistered securities contained in section 5 of the Securities Act of 1933. However, this is not a problem for invcstors whose activitics are so unlike those of underwriters or dealers that they are confident of qualifying for the exemption of section $4(1)$.

112. The meaning of the term "net lease" is discussed in note 142 infra.

113. See text accompanying note 40 supra. 
used the percentage rental term in finding that the restaurant was a common enterprise and in finding that the plaintiff was looking to the defendants' efforts for her profits. In neither respect is it clear that the overage was critical to the conclusion, but it is obvious that the court's decision was made easier by the presence of some participation in success. ${ }^{114}$ This reliance on the percentage provision is somewhat surprising in light of the term's apparently minor role in negotiation of the sale: plaintiff was approached on the basis of an investment with annual return of 10.4 percent; the total amount of the investment, and thus the specific amount of rental payments would depend on as-yet-undetermined construction costs. ${ }^{115}$ Neither the pleadings nor the descriptive literature supplied by the seller's realtor ${ }^{116}$ indicate that the overage was of importance to the desirability of the investment. The court's interest in the percentage provision apparently arose from the position taken in the defendants' brief that the central issue was whether a percentage lease was a security. ${ }^{117}$ In contrast, the plaintiff's formulation of the issue was whether the "investment package," 118 consisting of property subject to a leasehold in a party that had promoted the transaction, was a security. As viewed by the plaintiff, the percentage provision was an incidental term, not the controlling characteristic. ${ }^{119}$ For reasons to be discussed, the plaintiff's view is the correct one, the defendants failed to confront the central issue, and the court derived too much comfort from the presence of a percentage rental term.

To treat sale-leasebacks as securities only when they contain a percentage rental term would be inconsistent with economic reality. The primary inducement to invest in the typical sale-leaseback is a healthy annual return from financially sound tenants or subtenants. ${ }^{120}$ Equity participation, along with residual values, and, in some cases, depreciation fiows are secondary considerations. The

114. The court refers to the overage rentals at several points. However, it never does so in a manner that indicatcs their precise importance to its decision. See $337 \mathrm{~F}$. Supp. at 1251.

115. "Agreement of Sale and Deposit Receipt," Term and Condition of Sale Number 16, attached as Exhibit B to Affidavit of Robert M. Tuller, filed in support of Plaintiff's Brief.

116. See Exhibit A to Affidavit of Robert M. Tuller, filed in support of Plaintiff's Brief.

117. See Defendants' Brief at 4, 6-7.

118. The characterization as an "investment package" is, of course, highly suggestive that the transaction was akin to a security, and was used frequently in the plaintiff's brief. It is noteworthy, however, that the term was also used in the affidavit of the realtor who sold the property to Huberman. See Affidavit of Robert M. Tuller, accompanying Plaintiff's Brief.

119. Plaintiff's Brief at 4, 8-10.

120. See notes $11,16-20$ supra and accompanying text. 
percentage term is viewed primarily as a hedge against inflation and is a fringe attraction that has become popular only in recent years. ${ }^{121}$ Such a minor and easily-foregone characteristic should not be the determinant of federal antifraud protection.

In addition, placing such emphasis on the percentage term would do violence to the general thrust of the federal concept of a security. As has been noted, ${ }^{122}$ the securities acts do not restrict themselves to equity securities; rather, they explicitly encompass such fixedobligation instruments as notes, bonds and debentures. While it is true that most arrangements heretofore deemed "investment contracts" have been equity participation schemes, ${ }^{123}$ this is not conclusive that all must be so classified. Indeed, one recent case has found a fixed-obligation instrument to be an investment contract. ${ }^{124}$ Further, it can be argued that the Howey language does reach fixedobligation financing methods: "profits" can readily mean nothing more than a return in excess of the original investment, ${ }^{125} \mathrm{a}$ form of

121. Compare Weil 66,68 (1971) (indicating that percentage terms are typical and are used primarily as hedges against inflation) with MAISEL 387 (no indication that percentage terms were used) and R. RICKs, supra note 11, at 37-38, 109 (1964) (occasional, but apparently not typical, use by insurance company purchaser/lessors, with the suggcstion that growing emphasis on the equity aspects of real estate investment would lead to increasingly frcquent use).

122. See notes 76-77 supra and accompanying text.

123. Only one investment contract case dealing with a fixed-obligation arrangement has been found. See SEC v. Lake Havasu Estates, 340 F. Supp. 1318 (D. Minn. 1972). The reason that such cases have so rarely arisen seems plain cnough-fixed-obligation financing instruments will typically fit within the speciflc statutory language, "any note, . . . bond, debcnturc ...."As has bcen mentioned, this is true of the sale-lcaseback's next-of-kin, the mortgage.

124. SEC v. Lake Havasu Estatcs, 340 F. Supp. 1318 (D. Minn. 1972) (sale of third-party contractual obligations, wherc seller guarantees the obligation and acts as collection agent for the purchaser).

In addition, the SEC has rccently refused to issue a no-action letter for a schemc in which the issuer's obligation was to be fixed. See Invcstment Diamonds, Inc., [1971-1972 Transfer Binder] CCH FED. SEC. L. REP. If 78,350 (SEC 1971). The issuer proposed to sell diamonds at retail prices subject to a repurchase agreement under which the investor was guarantecd "profits" of 5 percent per year. The investor at all times would have the option to sell his diamond to a third party, so that the investor could obtain the benefit of gencral market appreciation. However, as noted in the issuer's inquiry lettcr, "There is not a market for rcsale available at which an individual can dispose of a diamond he has purchased at retail and expect to realize the true value." $I d$. I 78,350 , at 80,907 . Thus, in praetice the investor would have to rely on the issuer's repurchase agreement for his profits.

125. This construction is consistent with the following language in State v. Gopher Tire \& Rubber Co., 146 Minn. 52, 56, 177 N.W. 937, 938 (1920):

[An investment contract is a contract or scheme for] the placing of capital or laying out of money in a way intended to secure income or profit from its employment. (Emphasis added).

This language is quotcd in Howey. SEC v. W.J. Howey Co., 328 U.S. 293, 298 (1946). Gopher 
"common enterprise" is present when an entrepreneur and his fixedsum obligee are both looking to the same enterprise for their expected returns, ${ }^{126}$ and the fixed-sum obligee is clearly depending on efforts of another when his return depends on the entrepreneur's being sufficiently successful to meet the fixed obligations. Moreover, under Coffey's general test for a security ${ }^{127}$ the percentage term would make no difference whatsoever; whether it is present or not, the same risk to the initial investment remains-a defaulting tenant would leave the purchaser holding property whose value would depend primarily upon successful employment in a particular enterprise which had failed. Finally, it should be noted that the presence or absence of a percentage term does not affect the fact that a sale-leaseback is a form of financing whereby the capital of passive investors is made available to a promoter in his profit-seeking activities. ${ }^{128}$ In summary, the various considerations and tests relevant to defining a security either lead to or are not inconsistent with the conclusion that a saleleaseback is within the definition, whether or not the lease provides for rentals that escalate with the lessee's revenues.

\section{Purchase from a Party Unrelated to the Lessee}

Since the seller and the lessee were different parties, the transaction in Huberman was not a pure sale-leaseback. However, the plaintiff alleged that fraudulent representations were made "by each of the defendants, and [that] each of the defendants [was] under the control and direction of each of the remaining defendants." 129 The transaction could thus be considered as one in which the seller was sufficiently related to the lessee as to be a pre-arranged conduit for an

Tire was apparently the first case to deal with the "investment contract" issue and was acknowiedged by the Supreme Court as a source of its Howey test. Id.

That "profits" should mean no more than return, either fixed or variable, in excess of initial investment has the support of commentators. See Coffey 403; Long, supra note 2, at 144, 175 76. However, some case law is more restrictive, requiring that the investor share in profits of the enterprise. See Emery v. So-Soft of Ohio, Inc., 94 Ohio L. Abs. 357, 366, 199 N.E.2d 120, 124 (Ohio Ct. App. 1964); Commonwealth ex rel. Pa. See. Comm'n v. Consumers Research Consultants, lnc., 414 Pa. 253, 255-56, 199 A.2d 428, 429 (1964).

126. This assertion involves the issue raised in note 44 supra and is a result of the ambiguity of "common enterprise."

127. See notes $82-92$ supra and accompanying text.

128. See notes 93-97 supra and accompanying text for the proposition that the Supreme Court understands protection in these circumstances to be the seeurities legisiation policy that. underlies its Howey test.

129. Huberman Complaint 5-6, para. 25. 
investment in the lessee's enterprise. ${ }^{130}$

A more difficult question would arise if the seller and the lessee were completely independent, such that the project was sold subject to the lease but without the assistance of the lessee. In the latter situation, clearly no investment is made in the seller's enterprise, for neither seller nor buyer have, by virtue of the sale, any continuing claims on or relations with each other. Further, it is difficult to conceive of the transaction as an investment in the lessee's enterprise, since no cash goes to the lessee. These considerations may prevent the transaction from satisfying either the Howey test (requiring invcstment in a common enterprise), or the risk capital test (requiring that the investor supply risk capital to an enterprise controlled by another), and may also prevent the transaction from qualifying under the general policy of protecting those who supply capital, upon the promise of profit, for the use of others. (On the face of the transaction, the investor supplies nothing more than sale proceeds to the seller and rental services to the lessee.) ${ }^{131}$ In any case, even if the various investment contract tests are not satisfied, the sale by a party unrelated to the lessee can still involve a security. The investment contract tests focus on whether a security is issued to an initial investor, whereas when the sale is by a party unrelated to the lessee, the question is whether the transaction involves a security that has previously been issued. ${ }^{132}$ The antifraud protection of the securities acts

130. Whether the developer and lessee so viewed the transaction, such that actual construction of the restaurant depended on obtaining a buyer, is difficult to determine. On the face of the lease, the developer was bound to supply the improved property in any case. See Lease dated March 3, 1969, accompanying the Huberman Complaint. However, construction did not commence until approximately the time Huberman agreed to the deal, several months later than originally scheduled. Affidavit of Robert M. Tuller, at 3 and Exhibit A thereto, accompanying Plaintiff's Brief.

131. The basis on which these objections might be met is that in economic reality the purchaser does supply capital to the enterprise, inasmuch as the property which he now owns but which is used by the enterprise not only is a capital asset in his own hands but also frces the enterprise of reliance on alternative sources of financing exactly to the extent of a cash investment equal to the property's market value.

132. The assumption that sale-leaseback property retains its security status in subsequent transfers appears sound in light of the treatment of other securities; for example, common stock is a security regardless of who sells it. However, a distinetion could be drawn on grounds that the common stock is a security by virtue of specific inclusion in the statute, whereas the saleleaseback is included by virtue of a judicial test which concentrates on the characteristics of the particular transaction. (For the argument that sale, even by a lessor who is unrelated to the lessee, does itself satisfy the transactional investment contract test, see note 131 supra.) A number of replies may be made to this distinction. First, since the investment contract cases have all involved the initial issuance of a security, it is natural that the tests they use should be 
reaches beyond initial investors to subsequent purchasers of a security. If a security was created in the earlier transaction whereby the seller agreed to supply real property to the lessee in exchange for rental payments, then the purchaser is accorded the protection of section $10(\mathrm{~b})$ and rule $10 \mathrm{~b}-5^{133}$ against fraud practiced not only by the seller but also by the lessee. ${ }^{134} \mathrm{~A}$ subsequent investor in saleleaseback property is therefore accorded securities act protection even if the lessee does not participate in the subsequent transaction, since the initial sale of the property subject to the lease created a security. ${ }^{135}$

However, the result is not as clear if the seller, without direction from a prospective lessee, acquired property, improved it, and solicited a tenant or tenants. At this point the issue becomes whether or not an ordinary commercial lease is a security. Although this ques-

cast in terms of the original transaction; certainly, such cases are not conclusive of the rights of subsequent purchasers. Second, the statutory term "investment contract" suggests documents with an existence and security status independent of the process by which they are crcated (if documents in the case of the sale-leascback are rcquired, they would be the deed and the lease to which the dceded property is subject). Third, the subsequent purchaser of an investment contract has no less need than subscquent purchasers of other securities for protection against deviations by the issuer from his original representations and commitments, and for protection against misrcpresentations by the seller-whether one is dealing with an invcstment contract or other securities, the subsequent purchaser values the security on the basis of these various representations and commitments. Fourth, whcther the original transaction involvcs issuance of an investment contract or some other security, the price which the issuer can obtain depends heavily on the initial investor's opinion of the security's resale value; that is, whatever type of security may be involved, if its security status is not retained, the initial investor faces the danger of being lockcd into an investment which is more valuable to him than to potential buyers, and this rcduced liquidity would depress the price he is willing to pay for the security.

133. It should be noted that these apply to "the purchase or sale" of securitics, and are not directed merely at fraud practiced in the issuance of a seeurity. SEC rule 10b-5, I7 C.F.R. § 240.10b-5 (1972).

134. Unlike common law fraud, rule IOb-5 does not rcquire contractual privity between the defrauding and injured parties, at least whcre the plaintiff's injury arises from fraudulent issuance to the party from whom he purchases the security. See Texas Continental Life Ins. Co. v. Bankers Bond Co., 187 F. Supp. 14, 25 (W.D. Ky. I960), rev'd on other grounds, 307 F.2d 242 (6th Cir. 1962). The circuit court specifically approved the lower court's holding on the privity issue, stating: "It was not necessary that there be privity between plaintiff and the defendants in the salc of the bonds." 307 F.2d at 249.

More frequently, the privity issue has arisen in the situation where the plaintiff purchases from a third party at an inflated price due to the defendant's false representations to a fourth unrelated party. Courts have split on this issue. Compare Joseph v. Farnsworth Radio \& Television Corp., 99 F. Supp. 701 (S.D.N.Y. 1951), aff'd per curiam, I98 F.2d 883 (2d Cir. 1952) (insufficient privity) with Gann v. Bernzomatic Corp., 262 F. Supp. 301 (S.D.N.Y. I966) and Cochran v. Channing Corp., 211 F. Supp. 239 (S.D.N.Y. 1962). See R. Jennings \& H. Marsh, Securities Regulation Cases and Materials 926-28 (2d ed. I968).

135. See notes $42-101$ supra and accompanying text. 
tion may seem startling, it must be considered because the principles supporting the argument that a sale-leaseback is a security also suggest that all commercial leases are securities. ${ }^{130}$ This Note will conclude with a fuller explanation of the foregoing assertion, and with an attempt to draw a rational, meaningful line somewhere between a sale-leaseback and the ordinary commercial lease. The resolution that will be suggested is not completely satisfactory, but it is believed to be sufficiently non-arbitrary to avert the conclusion that since including a sale-leaseback as a security forces one to include too much, the sale-leaseback itself should be excluded.

\section{The Ordinary Commercial Lease}

The ordinary lease seems to be nothing more than a sale of services to the lessee, and the term "security" may have little meaning if it is so broad and unrestricted that every commercial lessee issues a security to his lessor. However, approaching this problem through a liberal Howey test, one could conclude that the ordinary lease is indeed a security, for the purchaser is expecting income from the efforts of another party (albeit not the seller), ${ }^{137}$ and he is investing in a common enterprise in that the income from his investment, like that of the sale-leaseback lessor, depends upon the success of the lessee's business. ${ }^{138}$ On the other hand, it can be argued that execution of a lease involves neither a sale nor an investment and is thus not within the reach of securities legislation or cases. However, the point is not compelling, for a lease is little different in this respect from a secured bond-capital is provided to an enterprise which promises periodic payments for so long as it retains the capital. The principal difference is that bonds are issued to those who supply capital in the form of cash, while leases are issued to those who supply it in kind.

Aside from being troubling, the inability to exclude ordinary leases from the definition of a security emphasizes a basic weakness

136. Non-commercial leases cannot qualify for security status under any circumstances, for in such cases the lessor will never be providing financing for another person's profit-making enterprise. See text accompanying note 96 supra.

137. The Howey language, quoted at note 36 supra, does not require that the purchaser rely solely on the efforts of the seller; rather, it refers to profits expected "solely from the efforts of the promoter or a third party" (emphasis added). Subsequent decisions have held that the third party need not be related to the seller. See cases cited in note 55 supra.

138. See text accompanying note 38 supra for the Huberman court's handling of the common enterprise element in sale-leaseback financing. For a discussion of fixed-rental sale-leasebacks, see notes 113-28 supra and accompanying text. 
of substituting the Howey formula for direct consideration of underlying policy objectives-literally applied it is too infiexible to encompass all situations which should be reached, ${ }^{139}$ and liberally applied it is too free of policy restraints to stop short of situations that are inappropriate for inclusion. A better approach is to inquire whether in economic substance the transaction is, rather than a sale of rental services, one in which the lessor, upon expectation of profit, makes his capital available for use by another. ${ }^{140}$ However, in economic reality, a lessor is always providing capital to his lessee since the lessee is freed of the need to use alternative sources of financing to meet his real property requirements. Thus, the problem becomes one of defining those leasing situations in which the financing aspect is so strong as to justify securities protection. ${ }^{41}$

While all leases provide capital financing to the lessee, in ordinary commercial leases the lessee also receives numerous property management services. These often include maintenance, guard services, parking, utilities, cleaning and upkeep of hallways, exteriors, elevators and similar facilities, and payment of taxes. The basic issue in determining the reach of securities legislation into commercial leasing seems to be what service element is required to make a lease something othcr than a financing mechanism. It is here suggcsted that the rule should be a strict one, requiring for security status that

139. See notes 50-55 supra and accompanying text for a discussion of situations which have led courts to abandon literalism.

140. See notes 95-97 supra and accompanying text for a discussion of this policy-oriented approach and its application to sale-leasebacks.

It should be noted that the Coffey test, discussed at notes 82-92 supra and accompanying text, is superior to the Howey approach in dealing with this problem. While most of the elements of his test are present in the naked lease (risk of loss, no control over the enterprise, and expectation of a valuable benefit), it is not clear that the lessor furnishes any sort of initial value to the enterprise. Thus the issue is exactly the same as when the problem is approached through the underlying policy of protecting those who, upon the promise of profit, make their capital available to others: Is there an investment of capital or a sale of rental services?

141. It should be noted that the issue has been posed in terms of whether the lessee obtains financing, not in terms of whether the lessor invests in either the rental property or the enterprise. This distinction is important. If the securities acts are viewed as protecting all persons who make investments then one would perforce find securities in such transactions as the sale or leasing of rental property that is managed by one other than its owner, even if the manager is entircly unrelated to either the seller or the lessee. That protection of such investors is not the goal of the securities acts is fairly clear in Howey, where the Court states that legislative protection is for those investors who supply capital for the use of others. See notes 95-96 supra and accompanying text. In other words, security status rcquires not only that an investment be made, but that the investment provide financing to another person's business. The SEC does not faithfully observe this distinction. See Investment Diamonds, Inc., [1971-1972 Transfer Bindcr] CCH FED. SEC. L. REP. I 78,350 (SEC 1971). See note I24 supra. 
the lessor provide no property management services, either personally or through a manager, save for de minimis duties and such nondiscretionary and purely financial services as payment of taxes and insurance premiums. ${ }^{142}$ This strict rule is appropriate for two reasons. First, the test is easy to apply; it basically includes only those leases under which one lessee takes complete control of the entire property. ${ }^{143}$ Further, the formula avoids the difficulties of distinguishing between varying degrees of lessor involvement and of inquiring into whether the lessee views the leasehold as a form of financing. Second,

142. The line which is proposed here is different from that which defines a "net" lease. In the net lease the lessee takes all responsibility for taxes, insurance, utilities and maintenance, the result being that the rental payments represent the net periodic income on the lessor's investment. MAISEL 386. Lessor responsibility for these items should not necessarily provide an escape from security status, at least where the lessor's responsibility is purely financial and does not involve continuing discretion as to the appearance and operation of the property. For one thing, purely financial responsibility can be a matter of form rather than substance. Taxes and insurance are often susceptible to prior estimation and can be added to the rental payments; while costs of maintenance and utilities may generally be less predietable, reasonably reliable estimates are probably possible in some situations. However, for the sake of argument it will be assumed that these quantities are not accurately predictable, and that by accepting responsibility for them the lessor does in fact take a position of greater risk that is refiected in a rental premium over and above the expected additional costs. In this case the lessor is providing a form of rental service, that of bearing the risk of unexpectedly heavy expenses of real property ownership. However, the essential nature of the transaction is unchanged-it remains one in which the lessee obtains the use of the lessor's capital upon promise of a return to the lessor arising from minimally successful operation of the lessee's enterprise. The additional element of risk assumed by the lessor, in his capacity as insurer, gives the lessor neither increased control over the enterprise nor reduced dependence on the lessee's ability to produce sufficient income to meet the rental payments. Further, elimination of the "net" term does not affect the lessor's reliance on the lessee's representations concerning the stability and profitability of the enterprise; indeed, since the lessee is more likely to have the information needed to make projections of future taxes, repairs, insurance, and utilities, elimination of the "net" term introduces another uncertainty as to which reliance on the lessee is likely. Thus it seems preferable to rctain security status even where the lessor provides certain rental services, so long as these services are purely financial and involve no element of discretionary responsibility.

143. It would seem quite unusual for a lessee to take control of less than the entire property without depending on the lessor for those services, such as heat, physicarsecurity, and elevators, which are used in common with other tenants.

Exactly what constitutes the "property" could be a source of difficulty. Since the proposed test turns on whether the lessee pays the lessor to shoulder property management responsibilities, "property" should be broad enough to encompass those facilities which are necessary to a particular enterprise and are ordinarily provided by an owner/occupant. Thus, "property" would include the parking lot of a drive-in restaurant or suburban shopping center, but probably would not embrace parking facilities adjacent to a center-city office building. The multibuilding development, such as an office park, could prove particularly troublesome where entire buildings are rented by single tenants. In the case of suburban office parks it seems appropriate to include as part of the property the parking and grounds whieh the owner/occupant of a suburban building would normally provide for himself. 
the test is mindful that, despite their obvious financing aspect, leases are not reached by the direct terms of securities legislation. This legislative omission suggests that judicial interpretation should include a lease only when it is used precisely as securities are used-namely, to obtain financing and nothing more.

The foregoing considerations, together with the thought that a line must be drawn at some point in order to include as a security the sale-leaseback while excluding the ordinary lease, seem to outweigh the arbitrariness that is introduced by excluding some transactions in which the financing element is paramount. The proposed test excludes situations in which an entrepreneur's thin capitalization forces him to satisfy his real property needs by lease rather than purchase if he is willing to forego control of, for example, maintenance. This type of lease clearly is a financing transaction, but because it is something else in addition, it does not involve a security. While the line can thus be somewhat arbitrary, it nevertheless seems more satisfactory than any alternative. ${ }^{144}$

It should be noted that in proposing a line to separate security and non-security leasing transactions, no consideration has been given to the term of the lease. This factor would introduce great uncertainty and difficulty, not only as to the initial term sufficient for there to be a security, but also as to the point, if any, in the life of a lease at which it ceases to be a security. Further, no policy considerations aid in determining the proper periods, for the term of a financing arrangement normally has no effect on its security status. ${ }^{145} \mathrm{~A}$ shortterm lease is best viewed as analogous to other forms of short-term

144. One alternative would be for security status to depend on whether the lessee seeks the lease with a view to obtaining financing. However, this would introduce questions of intent into an area of law that has heretofore dealt only with objective considerations; further, it would yield different treatment for transactions that are identical save for the lessee's intent (a factor which is neither otherwise relevant to the lessor nor readily known by him).

Another possibility, which would be appropriate if securities legislation were considered to extend protection to all investors (as opposed to active entrepreneurs, see note 141 supra), would have security status turn on whether the lessor retains an agent to manage the property. This test would result in different treatment for transactions that are identical except for the way in which the lessor meets his management responsibilities, a faetor which is beyond the lessee's control and otherwise is of no importance to him.

145. An exception to this general rule appears in the definition of a security contained in the Securities Exchange Act of 1934. See note 7 supra. The definition excludes "any note . . . which has a maturity at the time of issuance of not exceeding nine months." However, Sanders v. John Nuveen \& Co., 463 F.2d 1075 (7th Cir.), cert. denied, 41 U.S,L.W. 3274 (U.S. Nov. 13,1972 ), narrowly construed this language to apply only to commercial paper and not to instrumcnts which were otherwise investment securities. Id. at 1080. 
financing, to be treated as a security if it otherwise meets the relevant standard.

\section{CONCLUSION}

This Note has considered the application of federal securities laws to sale-leasebacks in particular and, more generally, to real property leasehold transactions. It has concluded that the pure sale-leaseback is appropriately treated as a security and that the federal courts are likely to treat it as such. The Note has also concluded that a percentage rental term is not critical to the sale-leaseback's security status, and that a security can be created even though the lessor does not acquire the property from the lessee. Finally, it has been suggested that a commcrcial lease is a security, issued by the lessee, if the lessee obtains complete control of the property and in no significant way depends on the lessor for property management services.

The reach of the securities laws into the commercial leasing area is not easily determined, and the Howey test seems especially illsuited for defining the line between the sale of rental services and issuance of a security. The soundest approach is also the most general-the Supreme Court's perception that the securities acts are intended to encompass "the countless and variable schemes devised by those who seek the use of the money of others on the promise of profits." This, of course, is more a statement of policy than a test. As such, it must be tempered by concern for other policies, such as the need for legal effects which depend on recognizable, rational distinctions. It must also be tempered by the understanding that a statute addressing itself to "securities" is likely not intended to reach leases, which are readily distinguishable from securities in both lay and legal terminology, unless the lease is used purely as a financing mechanism and is devoid of those characteristics which make it also a sale of property management services. 